\title{
Japan: Oversight and Supervision of Financial Market Infrastructures (FMIs) — Technical Note
}

This paper was prepared based on the information available at the time it was completed in August, 2012. The views expressed in this document are those of the staff team and do not necessarily reflect the views of the government of Japan or the Executive Board of the IMF.

The policy of publication of staff reports and other documents by the IMF allows for the deletion of market-sensitive information.

Copies of this report are available to the public from

International Monetary Fund • Publication Services $70019^{\text {th }}$ Street, N.W. • Washington, D.C. 20431

Telephone: (202) 623-7430 • Telefax: (202) 623-7201

E-mail: publications@imf.org Internet: http://www.imf.org

\section{International Monetary Fund Washington, D.C.}


FINANCIAL SECTOR ASSESSMENT PROGRAM UPDATE JAPAN

OVERSIGHT AND SUPERVISION OF FINANCIAL MARKET INFRASTRUCTURES (FMIS)

TECHNICAL NoTE

August 2012

INTERNATIONAL MONETARY FUND

MONETARY AND CAPITAL MARKETS DEPARTMENT 
Glossary

Executive Summary

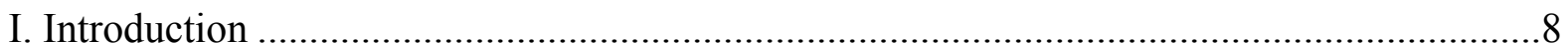

II. Description of the FMI supervision and oversight framework ....................................

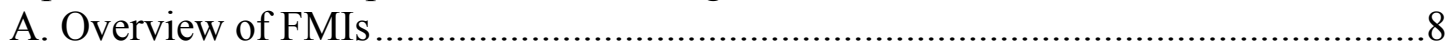

B. Overview of the Supervision and Oversight Framework ..................................... 12

C. Major Past and Ongoing Reforms ............................................................... 14

III. Main issues at stake ..................................................................................................... 15

A. Effectiveness of the Oversight/Supervision of the JGB FMIs ............................15

B. Oversight of Public-Owned FMIs .................................................................... 17

C. Cooperation Between Domestic Authorities....................................................... 18

D. Shock and Crisis Management.......................................................................20

E. Spillover Risk Stemming from FMI Interdependencies....................................25

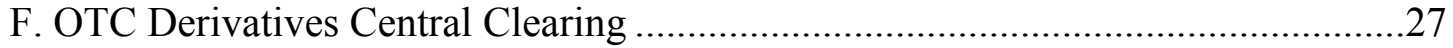

Tables

1. Main Recommendations on FMIs...............................................................................

2. Average Daily Volume and Value Processed by the Main FMIs in 2011 ........................11

Appendices

I. Overview of the Trading, Clearing and Settlement Organization ....................................29

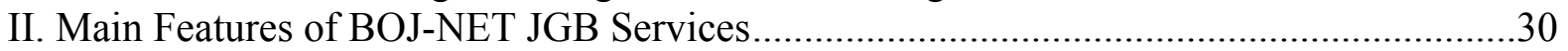

III. Main features of the Japan Government Bond Clearing Corporation (JGBCC) ...............32

IV. Overview of the Oversight and Supervision Framework for Major FMIs .......................36 


\section{GLOSSARY}

\begin{tabular}{|c|c|}
\hline $\mathrm{BOJ}$ & Bank of Japan \\
\hline BOJ-NET FTS & Bank of Japan-Financial Network System Funds Transfer System \\
\hline CCPs & Central Counterparties for financial instruments \\
\hline CDS & Credit Default Swap \\
\hline CPSS & Committee on Payment and Settlement Systems \\
\hline CLS & Continuous Linked Settlement \\
\hline CSD & Central Securities Depository \\
\hline DNS & Deferred Net Settlement \\
\hline DVP & Delivery Versus Payment \\
\hline FIEA & Financial Instruments and Exchange Act \\
\hline FSA & Financial Services Agency \\
\hline TFX & Tokyo Financial Exchange \\
\hline FXYCS & Foreign Exchange Yen Clearing System \\
\hline ICSD & International Securities Settlement System \\
\hline IOSCO & International Organization of Securities Commissions \\
\hline JASDEC & Japan Securities Depository Center \\
\hline JDCC & JASDEC DVP Clearing Corporation \\
\hline JGB & Japanese Government Bond \\
\hline JGBCC & Japan Government Bond Clearing Corporation \\
\hline JMA & Japan Meteorological Agency \\
\hline JSCC & Japan Securities Clearing Corporation \\
\hline LBJ & Lehman Brothers Japan \\
\hline MOF & Ministry of Finance \\
\hline MOJ & Ministry of Justice \\
\hline OSE & Osaka Securities Exchange \\
\hline OTC & Over the Counter \\
\hline PSA & Payment Services Act \\
\hline PSMS & Pre-Settlement Matching System \\
\hline PVP & Payment versus payment \\
\hline RTGS & Real Time Gross Settlement System \\
\hline $\mathrm{RCCP}$ & CPSS/IOSCO Recommendations for CCPs \\
\hline RSSS & CPSS/IOSCO Recommendations for SSSs \\
\hline SESC & Securities and Exchange Surveillance Commission \\
\hline SSS & Securities Settlement System \\
\hline $\mathrm{TCH}$ & Tokyo Clearing House \\
\hline TSE & Tokyo Stock Exchange \\
\hline
\end{tabular}




\section{EXECUTIVE SUMMARY}

The way Japanese authorities supervise and oversee post-trade financial market infrastructures (FMIs) is an essential issue in promoting and maintaining financial stability. Because well-functioning FMIs can vastly improve the efficiency, transparency, and safety of financial systems, but also can concentrate systemic risk, their appropriate supervision and oversight is critical. Therefore, this note reviews the oversight and supervision framework for systemically important FMIs in Japan. The analysis focuses on the effectiveness of oversight and supervision of the main securities settlement system (Bank of Japan Financial Network System Japanese Government Bond Services (BOJ-NET JGB Services)) and the main central counterparty for financial instruments (the Japanese Government Bond Clearing Corporation (JGBCC)) and is based on the relevant recommendations of the current Committee on Payment and Settlement Systems (CPSS)International Organization of Securities Commissions (IOSCO) standards.

There are 11 major FMIs located in Japan; three of them belong to the top 20 FMIs in the world. There are four interbank payment systems, two securities settlement systems (SSSs), and five central counterparties for financial instruments (CCPs). FMIs are critical elements of the Japanese financial sector and are highly relevant in terms of domestic financial stability. In terms of value of transactions, BOJ-NET Funds Transfer System (BOJ-NET FTS), the Japanese Real Time Gross Settlement System (RTGS), belongs to the top four large value payment systems worldwide, BOJ-NET JGB Services to the top five SSSs, and JGBCC to the top 10 CCPs. However, Japanese FMIs are mostly of a domestic nature, which make them less directly relevant in terms of global financial stability.

The supervision and oversight framework is fragmented. There is no uniform or comprehensive act in Japan that governs payment, clearing and securities settlement. Rather, several laws combine to form the legal basis for payment, clearing and securities settlement, as well as their supervision framework. There are five different authorities with supervisory and oversight authorities over the 11 major FMIs. They differ depending on the characteristics of the FMI.

Overall, the oversight/supervision of the JGB FMIs is effective and the authorities have driven fundamental structural reforms to strengthen the robustness and efficiency of FMIs in the past decade. In general, the law gives the FSA specific powers with regard to FMIs consistent with its responsibilities, including the ability to obtain information and induce change. Bank of Japan (BOJ)'s oversight policy and objectives are decided by its policy board and disclosed on its website both for the private sector operated Japanese FMIs and for offshore yen payment systems. One of the FSA and BOJ's objectives is to ensure that these FMIs comply with the CPSS and CPSS-IOSCO standards; to this end they aim at continuously assessing their compliance and inducing change where necessary. They also conduct onsite inspections/examinations and off-site monitoring. Major improvements have been undertaken in the past decade, in particular the implementation of real time gross settlement for all large-value payments, the introduction of liquidity saving features in the 
RTGS, the development of delivery versus payment (DVP) settlement for all types of securities, and the reduction of risks in clearing and settlement of JGBs.

A few actions are nevertheless recommended to further improve the oversight and supervision framework. They are the following: the list of systemically important FMIs could be officially disclosed; BOJ could better communicate on the oversight of publicowned FMIs; the FSA could disclose its FMIs supervision policy; ${ }^{1}$ and assessments against the CPSS-IOSCO standards could be more detailed and their clarity further improved on a few essential issues. In particular, the legal basis of settlement finality for fund transfers should be further clarified through an external legal opinion. Finally, domestic authorities should continue to develop and further clarify their cooperation arrangements in order to facilitate the exercise of their responsibility both in normal circumstances and in times of market stress.

Lessons from the latest crises have been drawn and led the authorities to take actions. However structural improvements are still pending three years after Lehman's default. Overall, Japanese FMIs weathered September 2008 and March 2011 crises well and were able to avoid systemic disruption. At the same time, the Lehman Brothers Japan (LBJ) bankruptcy has revealed several challenges that the authorities and market participants have decided to address, however this is still ongoing. In particular, JGBCC has been strengthening its operational and risk management functions through a number of measures, but the contingency funding arrangements are still to be improved. Strengthening JGBCC risk management is of particular importance in view of the objective to expand the use of the CCP. And, given the deteriorating financial conditions in some parts of the world and the associated rising risk of default, it is essential that the CCP and the authorities are ready to handle the default of the largest participant. In addition, the authorities should put in place coordinated contingency plans to deal with a potential failure of the CCP in line with the outcome of the ongoing international discussions. The resilience to the Great East Japan Earthquake reflected the constant efforts made by FMIs and financial institutions to put in place robust business continuity arrangements prior to the disaster. Taking into account the lessons from the earthquake, BOJ and FSA have identified ways for FMIs and market participants to further enhance their business continuity arrangements, including organization of street-wide testing exercises on a regular basis.

The spillover risk stemming from interdependencies with overseas FMIs has increased in the past decade but remains relatively limited in Japan. The authorities are monitoring some of the sources of spillover risks. However, they do not currently get sufficient information on offshore yen central clearing, but discussions are taking place in the Over the Counter (OTC) Derivatives Regulator Forum to develop information sharing agreements on individual FMIs, including LCH Clearnet limited. It is important that the authorities continue monitoring the spillover risk stemming from interdependencies with overseas FMIs and that they remain associated to the relevant international supervisory and oversight arrangements.

\footnotetext{
${ }^{1}$ The FSA intends to define and disclose its policy in relation to FMIs when the CPSS/IOSCO Principles for FMIs are finalized in the course of 2012.
} 


\begin{abstract}
Japan has undertaken the necessary steps to meet the G-20 commitment to centrally clear all standardized OTC derivatives. While the OTC derivatives market in Japan is still smaller in scale than those in the United States and Europe, the notional amount of yen-denominated single-currency interest rate derivatives was estimated at around US\$65 trillion at end-June 2011. Transactions between domestic participants are currently cleared on a bilateral basis, and transactions between overseas counterparties are mostly cleared in LCH Clearnet limited and on a bilateral basis. In December 2011, Japan was the only jurisdiction, with the United States, that had adopted legislation mandating central clearing of standardized OTC derivatives by the end of 2012. Central clearing services for some yen denominated OTC derivatives will be offered domestically in parallel with offshore clearing. This will allow direct access to clearing activities by smaller domestic participants and enable authorities to exercise oversight of yen denominated derivatives domestic trading and clearing activity. However, the coexistence of several CCPs clearing the same type of transactions is likely to decrease the netting effect and increase the amount of posted collateral.
\end{abstract}




\section{Table 1. Japan: Main Recommendations on FMls}

\begin{tabular}{|c|c|c|}
\hline Recommendations and Authority Responsible for Implementation & Priority & Timeframe $1 /$ \\
\hline $\begin{array}{l}\text { Further develop and clarify cooperation arrangements among domestic } \\
\text { authorities with respect to FMIs in order to facilitate the exercise of their } \\
\text { responsibility both in normal circumstances and in times of market stress } \\
\text { (FSA, Ministry of Finance (MOF), Ministry of Justice (MOJ), Securities and } \\
\text { Exchange Surveillance Commission (SESC), BOJ) }\end{array}$ & Medium & Near term \\
\hline Disclose the list of systemically important FMIs (BOJ, FSA) & Medium & Near term \\
\hline Disclose FMI supervision policy (FSA) & Medium & Near term \\
\hline $\begin{array}{l}\text { Further improve the clarity of assessments against the CPSS-IOSCO } \\
\text { standards (FSA, BOJ) }\end{array}$ & Medium & Immediate \\
\hline Better communicate on the oversight of public-owned FMIs (BOJ) & Medium & Near term \\
\hline $\begin{array}{l}\text { Continue monitoring the spillover risk stemming from interdependencies } \\
\text { with overseas FMIs (FSA, BOJ) }\end{array}$ & High & Immediate \\
\hline $\begin{array}{l}\text { Participate in the supervision of LCH Clearnet limited through cooperative } \\
\text { arrangements (FSA, BOJ) }\end{array}$ & Medium & Near term \\
\hline Secure the availability of the contingency funding for JBGCC (FSA, BOJ) & High & Immediate \\
\hline $\begin{array}{l}\text { Investigate the need to implement segregation and portability of customers' } \\
\text { positions and collateral in JGBCC (FSA, BOJ) }\end{array}$ & Medium & Near term \\
\hline $\begin{array}{l}\text { Develop coordinated contingency plans to deal with a potential failure of } \\
\mathrm{CCPs} \text {, in line with the outcome of the ongoing discussions on this } \\
\text { issue at the international level (FSA, BOJ, MOF) }\end{array}$ & High & Near term \\
\hline
\end{tabular}

1 " "Immediate" is within one year; "near-term" is one to three years; "medium-term" is three to five years. 


\section{INTRODUCTION}

1. The way Japanese authorities supervise and oversee post-trade financial market infrastructures is an essential issue in promoting and maintaining financial stability. Because well-functioning FMIs can vastly improve the efficiency, transparency, and safety of financial systems, but also can concentrate systemic risk, their appropriate supervision and oversight $^{2}$ is critical to the public policy goals. In this note, FMIs cover payment systems, securities settlement systems ${ }^{3}$ and central counterparties.

\section{Therefore, the note reviews the oversight and supervision framework for} systemically important FMIs in Japan. ${ }^{4}$ The analysis focuses on the effectiveness of oversight and supervision of the main SSS (BOJ-NET JGB Services), and the main CCP (JGBCC) and is based on the relevant recommendations of the current CPSS-IOSCO standards. ${ }^{5}$ Building on this analysis, the note addresses a number of issues that are relevant in the current Japanese and international context. The remainder of this note is structured as follows: Chapter II provides an overview of the Japanese FMIs, describes their oversight and supervision framework, and outlines the main past and ongoing reforms; and Chapter III discusses the following main issues: effectiveness of the oversight/supervision of the JGB FMIs, cooperation between domestic authorities, oversight of public-owned FMIs, shock and crisis management, spillover risk stemming from FMI interdependencies, and OTC Derivatives central clearing.

\section{DESCRIPTION OF THE FMI SUPERVISION AND OVERSIGHT FRAMEWORK}

\section{A. Overview of FMIs}

3. There are 11 major FMIs ${ }^{6}$ located in Japan (see Appendix I for the graphical overview of Japanese FMIs). Among them, four are interbank payment systems, two are SSSs, and five are CCPs.

\footnotetext{
${ }^{2}$ As defined in the CPSS report on "Central Bank Oversight of Payment and Settlement Systems" Bank for International Settlements, Basel, 2005, "Oversight of payment and settlement systems is a central bank function whereby the objectives of safety and efficiency are promoted by monitoring existing and planned systems, assessing them against these objectives and, where necessary, inducing change."

${ }^{3}$ In this note, securities settlement systems also include central securities depositories.

${ }^{4}$ This note was prepared by Christine Sampic, Senior Financial Sector Expert, Monetary and Capital Markets Department. She is grateful to the staff of the BOJ, the FSA and other agencies, and for the comments and guidance provided by Messrs Towe and Das and other members of the FSAP team.

${ }^{5}$ CPSS-IOSCO Recommendations for Securities Settlement Systems (RSSSs) and CPSS-IOSCO

Recommendations for CCPs (RCCPs).

${ }^{6}$ The term "major" is used by the authorities without being officially defined.
} 
4. The four interbank payment systems are: (1) the BOJ-NET FTS; (2) the Foreign Exchange Yen Clearing System (FXYCS); (3) the Zengin System; and (4) bill and check clearing systems.

- The BOJ-NET FTS is a RTGS operated by the BOJ that processes funds transfers over the accounts that financial institutions hold with BOJ. It is used to settle a wide range of payments including interbank money market transactions, large-value retail credit transfers, the cash legs of JGBs and other securities transactions, the net positions arising from retail payment systems, and transactions related to BOJ's money market operations.

- $\quad$ The FXYCS is a large-value payment system owned by the Japanese Bankers Association and its IT system is provided and operated by BOJ. It processes yen payments resulting from foreign exchange transactions, transactions in the euroyen market, and cross-border retail transfers. Payment instructions submitted to FXYCS are routed to BOJ-NET FTS for settlement on an RTGS basis.

- $\quad$ The Zengin System is the interbank clearing system for domestic retail credit transfers. Zengin Net acts as a central counterparty. The net positions arising from the Zengin System are settled over BOJ-NET FTS.

- Bill and check clearing systems are located across Japan with major ones operated by the regional bankers associations. The net positions arising from major bill and check clearing systems are settled over BOJ-NET FTS.

5. In addition, CLS (Continuous Linked Settlement) offers payment-versuspayment (PVP) settlement of foreign exchange transactions in 17 currencies, including the yen. Launched in September 2002 to eliminate foreign exchange (FX) settlement risk, CLS is a worldwide FX transactions system, based in New York. For the yen, pay-ins and pay-outs to and from CLS Bank are processed over the BOJ-NET FTS.

6. There are two major SSSs in Japan: the BOJ-NET JGB Services system ${ }^{7}$ for JGBs, owned and operated by BOJ, and the Japan Securities Depository Center (JASDEC) for securities other than JGBs, including stocks, corporate bonds, commercial paper, municipal bonds, convertible bonds, investment trusts, exchange traded funds and real estate investment trusts (see Appendix II for the description of BOJ-NET JGB Services). All securities have been dematerialized during the past decade except for unlisted stocks and are settled in bookentry systems offering DVP settlement.

\footnotetext{
${ }^{7}$ In this note, BOJ-NET JGB Services cover both the JGB Book-entry System, which is an arrangement for processing transfers of JGBs by crediting and debiting accounts of participating institutions and BOJ-NET JGB Services, which provides online processing services for the JGB Book-entry System.
} 


\section{Since 2002, three independent CCPs have been established in Japan.}

Japan Securities Clearing Corporation (JSCC) was established in 2002 to provide clearing services for the transactions traded in securities and derivatives exchanges (Tokyo, Osaka, Nagoya, Sapporo, Fukuoka, TOKYO AIM) and Proprietary Trade Systems (SBI Japannext Co., Ltd, and Chi-X JAPAN, Ltd.). JSCC has also been providing clearing services for iTraxx Japan (index trading of CDS) since July 2011. ${ }^{8}$ Japan Government Bond Clearing Corporation (JGBCC) was established in 2003 to reduce the amount of JGB settlement under the real-time DVP system of the BOJ-NET JGB Services and to mitigate counterparty risk in JGB transactions (see Appendix III for a description of JGBCC). JASDEC DVP Clearing Corporation (JDCC) was established in 2003 for customer-side transactions in securities settled in JASDEC. In addition, Tokyo Financial Exchange (TFX) and Osaka Securities Exchange (OSE) internally clear transactions in listed derivatives and are licensed as CCPs.

\section{FMIs are critical elements of the Japanese financial sector and are highly} relevant in terms of domestic financial stability. In terms of value of transactions, in 2011, payments settled in BOJ-NET FTS in a single day were equivalent to 21.6 percent of GDP, those settled in BOJ-NET JGB Services represented 16.1 percent of GDP, and the transactions cleared in JGBCC amounted to 7.7 percent of GDP. BOJ-NET FTS belongs to the top four large value payment systems worldwide, BOJ-NET JGB Services to the top five CSDs, and JGBCC to the top 10 CCPs (but far away from the top four). However, Japanese FMIs are mostly of a domestic nature (only processing yen transactions and without direct link to overseas FMIs, except CLS), which make them less directly relevant in terms of global financial stability. The table below provides the average daily volume and value processed by the largest Japanese FMIs and CLS in 2011.

\footnotetext{
${ }^{8}$ From its launch on July 19 to end-November 2011 , JSCC has cleared $¥ 125.7$ billion-\$1.62 billion notional in CDS index trades.
} 
Table 2. Japan: Average Daily Volume and Value Processed by the Main FMls in 2011

\begin{tabular}{rrrrr}
\hline & \multicolumn{4}{c}{ Daily Average } \\
\cline { 2 - 5 } Payment systems & $\begin{array}{c}\text { Value } \\
\text { (JPY trillion) }\end{array}$ & $\begin{array}{c}\text { Value } \\
\text { (USD billion) }\end{array}$ & $\begin{array}{c}\text { Value } \\
\text { (in percent } \\
\text { of GDP) }\end{array}$ & $\begin{array}{c}\text { Volume } \\
\text { (thousand) }\end{array}$ \\
\hline BOJ-NET FTS, of which: & 101.4 & 1271.8 & 21.6 & 53 \\
Interbank transfers & 38.8 & 486.6 & 8.3 & 11 \\
DVP for JGBs & 37.3 & 467.8 & 8.0 & 10 \\
CLS (yen payments) & 32.4 & 406.4 & 6.9 & 86 \\
FXYCS & 11.5 & 144.2 & 2.5 & 26 \\
Zengin System & 10.5 & 131.7 & 2.2 & 5,693 \\
\hline
\end{tabular}

${ }^{*}$ Figures for the Zengin System show value and volume of cleared payments.

\begin{tabular}{rrrrr}
\hline & \multicolumn{4}{c}{ Daily Average } \\
\cline { 2 - 5 } $\begin{array}{c}\text { Securities Settlement } \\
\text { Systems }\end{array}$ & $\begin{array}{c}\text { Value } \\
\text { (¥trillion) }\end{array}$ & $\begin{array}{c}\text { Value } \\
\text { (US\$ billion) }\end{array}$ & $\begin{array}{c}\text { Value } \\
\text { (in percent } \\
\text { of } \\
\text { GDP) }\end{array}$ & $\begin{array}{c}\text { Volume } \\
\text { (thousand) }\end{array}$ \\
\hline $\begin{array}{r}\text { SOJ-NET JGB Services } \\
\text { SASDEC* which: }\end{array}$ & 75.6 & 948.2 & 16.1 & 16 \\
Commercial Paper & -- & -- & -- & 337 \\
Corporate and other bonds & 5.0 & 62.7 & 1.1 & 1 \\
Investment trusts & 0.9 & 11.3 & 0.2 & 2 \\
\hline
\end{tabular}

* Figures for JASDEC show the total amount of issuance, transfer, and redemption made on the book-entry transfer system for each type of security, however the value of book-entry transfers for stocks is not available as JASDEC only collects and publishes figures on the "number of shares" transferred; therefore the total amount is not available either.

** Volume for stocks show the number of shares (not the number of transfers processed).

\footnotetext{
${ }^{9}$ Market rate, 2011 period average $=79.73$.

${ }^{10} 2011$ Gross Domestic Product SA $=¥ 468,425$ billion (based on quarterly estimates)
} 
Daily Average

\begin{tabular}{r|r|r|r|r|}
\cline { 3 - 5 } \multicolumn{1}{c}{ CCPs } & \multicolumn{5}{c}{$\begin{array}{c}\text { Value } \\
\text { (¥ trillion) }\end{array}$} & $\begin{array}{c}\text { Value } \\
\text { (US\$ billion) }\end{array}$ & $\begin{array}{c}\text { Value } \\
\text { (in percent } \\
\text { of GDP) }\end{array}$ & $\begin{array}{c}\text { Volume } \\
\text { (thousand) }\end{array}$ \\
\hline JGBCC $^{*}$ & 35.9 & 450.3 & 7.7 & -- \\
\hline JSCC $^{*}$ & 1.7 & 21.3 & 0.4 & -- \\
\hline JDCC $^{*}$ & 0.9 & 11.3 & 0.2 & 84 \\
\hline
\end{tabular}

* Figures for JGBCC, JSCC, and JDCC show the value and volume of transactions cleared by each CCP.

\section{B. Overview of the Supervision and Oversight Framework}

9. The supervision and oversight framework is fragmented. There is no uniform or comprehensive act in Japan that governs payment, clearing and securities settlement. Rather, several laws combine to form the legal basis for payment, clearing and securities settlement, as well as their supervision framework. Overall there are five different authorities with supervisory and oversight authorities on the 11 major Japanese FMIs. They differ depending on the characteristics of the FMI. Even when the FSA is in charge, different divisions are involved depending on the FMI: the Market division decides the supervision policy of FMIs regarding security settlement and the Bank I division and the supervisory coordination division cooperate to decide the supervisory policy on the FMIs regarding payment settlement. The table in Appendix IV provides an overview of the oversight and supervision authorities according to the type of FMI.

10. The Payment Services Act (PSA), which was enacted in April 2010, provides the legal framework for the supervision of payment clearing institutions, but not for all payment systems. The PSA allows nonbanks to provide funds transfer services that only banks were previously allowed to provide and sets out the regulatory framework for interbank payment clearing institutions. The power to license payment clearing institutions belongs to the Prime Minister, without delegation to the FSA Commissioner. The FSA is in charge of their supervision, including onsite inspection. The PSA covers payment systems with a central counterparty function and does not cover payment functions provided by banks and the central bank. ${ }^{11}$ Therefore, BOJ NET FTS and FXYCS are not licensed or supervised under the PSA. In practice, only one payment clearing institution (Zengin-net) is licensed under the PSA. Although there is no act that governs the supervision of FXYCS, the FSA cooperates with the Japanese Bankers Association as the owner of the system as needed in order to fulfill its missions, as stipulated in the Act for Establishment of the FSA (financial stability, depositor protection and financial facilitation), mainly through exchange of information. As for operators of bill and check clearing houses (e.g., regional bankers'

\footnotetext{
${ }^{11}$ Article 2(5), 64(2) of the PSA.
} 
associations), they are organized as non-profit incorporated associations and are subject to the Negotiable Instruments Act. This act stipulates that clearing houses should be designated by the MOJ, which is also in charge of examining the amendment of each clearing house rules. Although the FSA does not have the authority of inspection and supervision on bill and check clearing houses, it may decide to examine the operations of some of them in order to fulfill its missions, as it did when the Tokyo Clearinghouse introduced an electronic check clearing system.

\section{The Act on Book-Entry Transfer of Company Bonds, Shares, etc. (Book-Entry} Act) provides the supervisory framework for SSSs. Based on this act, JASDEC and the JGB Book-Entry System operated by BOJ ${ }^{12}$ are designated as SSSs by the competent authorities. The competent authorities for JASDEC are the FSA and MOJ and those for the JGB Book-Entry System are the FSA, MOJ, and Ministry of Finance (MOF). ${ }^{13}$ According to the act, the supervision is conducted on an equal footing by all authorities. In practice, the FSA is the leading authority with the exception of JGB Book-Entry System where the MOF plays the leading role, while the MOJ provides opinions on civil and commercial laws issues to the respective leading authorities. JGB Book-Entry System is subject to the same reporting duties as JASDEC, but the FSA, MOJ, and MOF do not have the authority to conduct onsite inspection of BOJ so as not to harm the independence of monetary policy. ${ }^{14}$

\section{The regulatory and supervisory framework for CCPs and exchanges is} segmented on the basis of the assets underlying transactions. The Financial Instruments and Exchange Act (FIEA) provides the supervisory framework for central counterparties for securities and financial derivatives. The licensing powers belong to the Prime Minister but most of other supervisory powers ${ }^{15}$ are delegated to the FSA Commissioner. Currently, the following five entities are licensed as central counterparties under the FIEA: JBGCC, JSCC, JDCC, TFX, and OSE. The FSA Commissioner delegates the powers to conduct onsite inspection to the SESC. CCPs for commodities (e.g., minerals or agricultural products) are not considered FMIs; they are supervised and regulated by the Minister of Agriculture, Forestry and Fisheries and/or the Minister of Economy, Trade and Industry in accordance with the underlying assets under the Commodity Futures Act. CCPs can clear both financial instruments and commodities provided they obtain both licenses from the relevant ministers.

\section{In parallel with the regulatory supervision, BOJ oversees payment and settlement systems operated by the private sector to ensure the safety and efficiency of}

\footnotetext{
12 JGB Book-Entry System is the legal name of the arrangement for book-entry transfer of JGBs, whereas BOJNET JGB Services is the name for the BOJ's service for online processing of JGBs.

${ }^{13}$ Article 285(1)(2) of the Book-Entry Act.

${ }^{14}$ Article 48 of the Book-Entry Act.

${ }^{15}$ Article 194-7(1) of the FIEA, Article 37-2(xiv-ii)(xiv-iii)(xiv-iv) of the Order for Enforcement on FIEA.
} 
payment and settlement arrangements in Japan. Article 1 of the Bank of Japan Act stipulates that BOJ's objectives are to issue banknotes, carry out currency and monetary control and ensure the smooth settlement of funds among banks and other financial institutions, thereby contributing to the maintenance of an orderly financial system. To achieve these objectives, the central bank provides various means of payment (i.e., banknotes and deposits in current accounts held in its books) and settlement services (BOJ-NET FTS and BOJ-NET JGB services). In addition, BOJ oversees payment and settlement systems in the private sector.

\section{Major Past and Ongoing Reforms}

14. Increasing safety and efficiency for large value payments settlement was a major structural improvement achieved during the past decade. In November 2011, the Next-Generation RTGS project was completed to bring additional levels of safety and efficiency to large-value payments. The project consisted of two pillars: (i) introducing liquidity-saving features into the BOJ-NET FTS (centralized queuing and offsetting facilities); and (ii) shifting large-value payments that were previously processed by privatesector deferred net settlement (DNS) systems, namely, the FXYCS and the Zengin System, to settlement on an RTGS basis in BOJ-NET FTS. As a result, large-value payments (payments in BOJ-NET FTS, FXYCS, and those equal to or larger than $¥ 100$ million in the Zengin System) are now settled on an RTGS basis. The introduction of liquidity-saving features has reduced the amount of funds and collateral that individual financial institutions needed for settlement. It has also enhanced the overall efficiency in the system by achieving earlier settlement with less amount of liquidity. Earlier settlement also contributes to the reduction of intraday settlement exposure, which, combined with the shift of large value payments from DNS to RTGS, has enhanced the safety of large value payments.

\section{BOJ is now in the process of developing a new system for the BOJ-NET which} will replace the current system in use since 1988, enhancing its efficiency and flexibility. The current BOJ-NET technical infrastructure, which supports both BOJ-NET FTS and BOJ-NET JGB Services, has gradually lost flexibility in responding to changing needs. The new BOJ-NET will resort to the latest information technology; offer greater flexibility for future changes; and provide enhanced accessibility including adoption of international communication and identification standards. The new BOJ-NET will provide basically the same functions as the current system through a new technical infrastructure, while some selected functions will be improved, integrated or abolished. The new system will also enable further extension of operating hours (currently from 09:00 to 16:30 for BOJ-NET JGB Services and to 19:00 for BOJ-NET FTS). The new BOJ-NET is planned to be implemented for funds and JGB transfers between autumn 2015 and early 2016.

\section{Reducing risks in clearing and settlement of JGBs has been another major} structural improvement of the past decade. Japan's securities settlement systems have undergone the following major reforms in recent years: (i) improvement of the legal 
framework; (ii) dematerialization of all securities except unlisted stocks; (iii) development of straight-through-processing (STP: automated processing of the entire lifecycle of securities transactions from trade confirmation to settlement); and (iv) introduction of a DVP settlement for all securities, except stock lending transactions between financial institutions and institutional investors.

17. Enhancing business continuity has also been an essential achievement. Since the September 11, 2011, terrorist attacks in the United States, authorities, FMIs and market participants have largely improved their business continuity arrangements and have been testing them regularly. Along with the business continuity plans developed by each market participant and operator of market infrastructure, measures to maintain a network of market participants in the event of a disaster (a market-wide business continuity plan) have been developed in money markets, foreign exchange (FX) markets, and securities markets. In each market, a dedicated web site has been developed as a tool for information sharing among market participants, contingency procedures have been prepared, and market-wide exercises have been conducted to assess the effectiveness of these arrangements. In addition, marketwide exercises across markets began to be organized in 2010 .

\section{MAIn ISSUES AT STAKE}

\section{A. Effectiveness of the Oversight/Supervision of the JGB FMIs}

\section{In general, the law gives the FSA specific powers with regard to FMIs consistent} with its responsibilities, including the ability to obtain information and induce change. The PSA, the Book entry act, and FIEA stipulate that the FMIs they cover shall be authorized, licensed or designated (respectively) by the FSA. However, some payment systems are not covered by any of these laws: BOJ-NET FTS, FXYCS, and bill and check clearing houses. ${ }^{16}$ The FSA has the power to obtain information from FMIs and inspect them (the right of inspection is entrusted with SESC, except for payment clearing institutions that are inspected by the Inspection bureau of the FSA). The FSA approves the rules of FMIs and their main changes. It can request FMIs to take improvement measures in order to maintain public benefits and investors protection. If FMIs do not take the required measures and violate the law, the FSA can order the change of management, the suspension of operations or the license's revocation.

\section{BOJ conducts oversight of FMIs to pursue its objective to "ensure smooth} settlement of funds among banks and other financial institutions," as stated in BOJ Act (Article 1, Paragraph 2), thereby contributing to the maintenance of stability of the financial

\footnotetext{
${ }^{16}$ It should be noted though, as explained above, that the FSA and MOF have the power of authorization, correcting the violation of acts, and collecting reports on BOJ-NET FTS. The FSA also exchanges information with FXYCS. As for the Bill and Check Clearing Houses, the MOJ has the power of designation and can collect reports on amended clearing house rules.
} 
system. BOJ oversees payment systems, securities settlement systems, and central counterparties on the grounds that they potentially pose systemic risk. However, precise responsibilities and powers on FMIs oversight are not explicitly set out in statute. For those FMIs that open accounts in its books, BOJ may enter into contract for onsite examination as it does with financial institutions. ${ }^{17} \mathrm{BOJ}$ also obtains information from and exchanges views with FMIs that do not use BOJ's services.

\section{BOJ's oversight policy and objectives are decided by its policy board and} disclosed on its website, ${ }^{18}$ but there is no published list of systemically important FMIs and the FSA has not disclosed its policy on FMIs' supervision yet. According to its oversight policy statement, BOJ's oversight covers all privately-owned FMIs. For systems determined to be systemically important, BOJ exercises oversight by monitoring such systems, assessing them against the safety and efficiency objectives and, where necessary, inducing changes. For systems determined to be less systemically important, BOJ exercises oversight mainly by monitoring such systems in order to gain an overview of overall payment and settlement arrangements in Japan. However, there is no published list of the FMIs that are determined to be systemically important. ${ }^{19}$ As for the FSA, there are no comprehensive guidelines for the supervision of FMIs or an annual supervisory policy as this is the case for other financial institutions (banks and insurances for example). The FSA intends to define and disclose its policy in relation to FMIs when the CPSS-IOSCO Principles for FMIs are finalized in the course of 2012.

\section{One of the objectives of the FSA and BOJ is to ensure that systemically} important FMIs comply with the CPSS and CPSS-IOSCO standards. To this end, they aim at continuously assessing their compliance and inducing change where necessary. They both expect the operators of systemically important FMIs to conduct self-assessment of the safety and efficiency of their respective systems against international standards and to publicly disclose the results of assessment. The FSA and BOJ cooperate with FMIs to ensure that self-assessments are conducted based on a common understanding and interpretation of the standards. They also conduct onsite inspection/examinations and off-site monitoring. As a result they may request FMIs to make changes. For example, JGBCC's risk management has improved since it started operation in 2005. In the self-assessment that is due to be published in early 2012, all RCCPs are observed, except for RCCP5 on financial resources,

\footnotetext{
${ }^{17}$ Paragraph 1(3) of the "Selection Criteria of a Counterparty of BOJ Current Account and Lending Transactions" (Policy Board Decision, June 26, 1998, last revised September 10, 2010).

${ }^{18}$ See the "Policy on Oversight of Payment and Settlement Systems," May 2010.

${ }^{19}$ Responsibility A of the CPSS Core Principles for Systemically Important Payment Systems states that the disclosure of major policies should include identifying systems which are systemically important, together with reasons for the judgment. Participants in such systems and any private sector operators need to be made aware whether their system is judged to be systemically important and, if it is, that the system will be expected to comply with the CPSIPS. Publication of the list of systemically important SSSs and CCPs is not a requirement under RSSSs or RCCPs since all SSSs and CCPs are deemed to be systemically important.
} 
which is broadly observed. As for BOJ-NET JGB services, the 2007 assessment shows that all RSSS are observed, with the exception of RSSS2 on trade confirmation.

22. The clarity of assessments could be further improved. Fairness and clarity of the authorities' assessments are generally good and main issues have been identified and followed-up. However, in some cases, assessments could be more detailed and the conclusions better supported. For example, with respect to the finality of transfers of funds, the assessment is vague although the CPSS-IOSCO recommendation on legal risk is considered observed both for BOJ-NET JGB Services and JGBCC. The authorities' analysis is that the settlement irrevocability defined in the rules of BOJ-NET FTS is not voidable under Japanese insolvency laws, and payment instructions that have been settled in BOJNET FTS will not be revoked in the course of insolvency proceedings. The legal basis of the settlement finality for fund transfers should be clarified through an external legal opinion. Another example relates to the transfer or liquidation of the positions and margins of customers of the defaulting participant. JGBCC's assessment report is very light on this important issue that deserves more arguments and further analysis, in particular since the CCP does not currently offer segregation and portability for participants' customers. As for BOJ-NET JGB Services, RSS7 on DVP should be elaborated further, in particular to explain the relationship between the statistics disclosed on the BOJ's website and the figures in the 2007 assessment, which differ substantially.

\section{Lessons from the latest crises have been drawn and led the authorities to take} actions, however structural improvements are still pending three years after Lehman's default. In the aftermath of the Lehman's default crisis, the authorities, in collaboration with the industry have developed roadmaps to further improve the clearing and settlement (see section $\mathrm{D}$ for further detail). ${ }^{20}$ Some of the actions that have been decided have been implemented, such as the introduction of charges for settlement fails, but important ones are still pending: the reduction of the settlement period to $\mathrm{T}+2$ is due to start in April 2012, ensuring the operational feasibility of obtaining the contingency funding needed by JGBCC to deal with the default of the participant with the largest exposure has not yet been finalized, and the DVP settlement for stock lending transactions among financial institutions and institutional investors (with either cash or securities pledged as collateral) is planned for January 2014. It would be sensible to speed up these reforms to further improve the clearing and settlement arrangements against potential crises in the future.

\section{B. Oversight of Public-Owned FMIs}

24. The two largest Japanese FMIs, which are among the top 10 FMIs worldwide in terms of transaction value, BOJ-NET FTS and BOJ-NET JGB Services, are owned and

\footnotetext{
${ }^{20}$ These reforms are described in BOJ reports: Payment and Settlement Systems Report 2009 and Payment and Settlement Systems Report 2010.
} 
operated by the central bank. According to the CPSS-IOSCO standards, where central banks themselves own or operate FMIs, they should apply, to the extent applicable, the same international standards to their own systems with the same rigor as other overseen systems. In addition, if a central bank is an operator of an FMI, as well as the overseer of private-sector FMIs, it needs to consider how to best address any possible conflicts of interest.

25. BOJ ensures that BOJ-NET FTS and BOJ-NET JGB Services comply with the CPSS and CPSS-IOSCO standards by assessing their compliance ${ }^{21}$ and inducing change where necessary. In August 2003, based on the results of its self-assessment that was disclosed on its website, the central bank concluded that BOJ-NET FTS complied with the 10 CPSS Core Principles for Systemically Important Payment Systems. Since then, the central bank has monitored the developments and changes in the environment surrounding the central bank's operation and oversight of payment and settlement systems, and has introduced structural improvements in its RTGS (settlement of all large value payments on a RTGS basis, introduction of liquidity saving features). Although changes to BOJ-NET FTS, including those related to the Next-Generation RTGS project, are reviewed against international standards internally, BOJ has not published updates to its 2003 self-assessment. The Bank also conducted and published a self-assessment of the JGB settlement system's compliance with the CPSS-IOSCO RSSSs in November 2007-JGB settlement system "observed" 17 out of the 18 recommendations, and "broadly observed" RSSS2 on trade confirmation.

26. BOJ could better communicate on the oversight of public-owned FMIs. BOJ's oversight policy clearly states that the central bank oversees private sector owned FMIs but does not describe how it applies the same standards to the FMIs it operates. The only reference to the latter is made in a footnote that explains that the Bank has assessed its payment system and JGB settlement system against international standards and published the assessment results. Therefore, it could be helpful to clarify in the next version of the policy statement that BOJ conducts the same type of oversight function whatever the status of the owner of the FMIs.

\section{Cooperation Between Domestic Authorities}

\section{Cooperation between authorities is essential to ensure a consistent} oversight/supervision approach, minimize reporting burden from FMIs, and avoid supervisory gaps. RCCP15 states that "A CCP should be subject to transparent and effective regulation and oversight. In both a domestic and an international context, central banks and securities regulators should co-operate with each other and with other relevant authorities." RSSS18 is also clear in this regard: "Securities settlement systems should be subject to

\footnotetext{
${ }^{21}$ The assessment of the central bank's own system is carried out by the oversight function and not by the operations function itself, each function reporting to a different management stream.
} 
transparent and effective regulation and oversight. Central banks and securities regulators should cooperate with each other and with other relevant authorities." Cooperative arrangements based on mutual assistance provide a mechanism whereby the responsibilities of an FMI's individual authorities can be fulfilled more efficiently and effectively. Cooperative arrangements should be managed to deliver regulation, supervision, and oversight consistent with each relevant authority's responsibilities and without prejudice to their statutory or other responsibilities. Cooperation also should minimize the duplication of effort and the burden on FMIs and the relevant authorities. Cooperation should seek to avoid inconsistency in policy approaches and reduce the probability of gaps in regulation, supervision, and oversight that could arise if authorities did not coordinate with each other.

\section{There are no comprehensive cooperative arrangements between the main authorities that have responsibilities over FMIs (BOJ, FSA, SESC, MOF, and MOJ).} The law does not define the respective role of the FSA, the MOF and the MOJ that supervise FMIs on an equal footing. It is therefore not clear which authority would have the last word in case of diverging opinions, which could hamper clear authorities' action. As for the relationship between BOJ and FSA, the only provision of the relevant acts, is that the Prime Minister can seek the BOJ's opinion, where necessary, before granting or revoking a regulatory license or taking any enforcement action on an interbank payment system or CCP. Although this has never happened, FSA and BOJ have been exchanging views on individual FMIs in light of this provision. There is no formal framework to facilitate the exercise of the authorities' responsibility both in normal circumstances and in times of market stress, such as a document describing the distribution of responsibilities and roles, the ways to share information, conduct assessments and manage crises.

29. In practice, coordination works to a large extent. As an example of such coordination, following the 2008 financial crisis, the FSA and BOJ identified a number of weaknesses in payment and settlement systems. The FSA called on market participants to develop roadmaps with concrete timelines for reducing risks in clearing and settlement arrangements for JGBs and stock-lending transactions. BOJ supported market participants in the development of the roadmap and in their deliberation and implementation of specific aspects of the initiatives. The FSA and BOJ also coordinate closely in the development of international standards such as CPSS-IOSCO Principles for Financial Market Infrastructures by discussing the appropriateness of the standards for FMIs in Japan. The FSA and BOJ jointly organize meetings with FMIs to enhance their understanding of the standards and exchange views on individual FMIs, for example when an FMI starts a new service or makes significant changes to its rules or systems. The authorities are of the opinion that coordination between FSA and BOJ has been effective including discussions on issues for improvement in each FMI.

\section{However, there is also evidence that cooperation is not as developed as it could}

be. While not a requirement under the current CPSS/IOSCO standards, the various authorities do not meet on a regular basis to exchange their views on individual FMIs. They 
had not conducted assessments jointly nor shared the ratings of their non-published assessments. FSA's on-site inspections and BOJ's on-site examinations are conducted separately in light of the different perspectives and objectives of the two institutions. In addition, it is not clear what would happen in case relevant authorities would have different opinions on decisions to take, in particular in time of crisis. That might hamper a prompt and adequate reaction from the authorities, which could have negative consequences.

\section{Domestic authorities should further develop and clarify their cooperation} arrangements in order to facilitate the exercise of their responsibility both in normal circumstances and in times of market stress. ${ }^{22}$ This is particularly relevant in Japan because of the complexity and fragmentation of the oversight and supervision framework. Authorities can consider a variety of approaches including information sharing arrangements, coordination of supervisory and oversight responsibilities for specific matters, and other cooperation arrangements. The definition of the distribution of roles between authorities is of particular relevance in times of market stress, to achieve public action efficiency.

\section{Shock and Crisis Management}

\section{Overall, Japanese FMIs weathered September 2008 and March 2011 crises well.}

From the analysis published by BOJ, ${ }^{23}$ it appears that, overall, the risk management measures embedded in payment and settlement systems functioned well during the Lehman Brothers Japan (LBJ) bankruptcy event. The filing for bankruptcy by LBJ caused a chain of settlement fails ${ }^{24}$ and resulted in intraday delays that lasted for several business days, but closing of LBJ's outstanding positions and rebuilding of positions by LBJ's counterparties were executed without significant delays in accordance with the rules of central counterparties and agreements between market participants. The level of settlement fails returned to normal in October for non-centrally cleared JGB transactions, and JGBCC was able to clear up most of the settlement fails for the transactions it cleared by the end of September. FMIs were therefore able to avoid a situation where principal risk materializes for a wide range of market participants, possibly leading to a chain of defaults. JGBCC was able to meet its obligations to non-defaulting participants within two weeks after the collapse of LBJ and the loss it incurred in replacing LBJ's positions was fully covered by LBJ's initial margins. In effect, the crisis has demonstrated the effectiveness of the various initiatives taken to reduce settlement risk, including introduction of CCPs, DVP for securities transactions, and PVP for

\footnotetext{
${ }^{22}$ The CPSS/IOSCO assessment methodologies states that the RCCP15 and RSSS18 are broadly observed when: "The framework for cooperation between the securities regulator and central bank and with other relevant authorities is not in place or does not work well."

${ }^{23}$ See BOJ Payment and Settlement Systems Report 2009 originally published in Japanese on January 5, 2010.

${ }^{24}$ A settlement fail refers to a situation in which a party has not received the relevant securities from the delivering party at the scheduled settlement date for reasons other than the creditworthiness of the parties to the transaction.
} 
foreign exchange transactions. It should be noted though, that markets were closed when LBJ's default occurred since it was holiday in Japan, which gave more time to all stakeholders to handle the situation.

\section{At the same time, the LBJ bankruptcy has revealed several challenges that need}

to be addressed. As LBJ went into default, an unprecedented number of fails occurred. This delayed the settlement of JGBs seriously and lowered market liquidity in the repo and government securities markets. Indeed, with growing concerns over the risk of fails, some market participants ceased engaging in new transactions, which resulted in reduction of market liquidity in the JGB and repo markets. ${ }^{25}$ As for JBGCC, the crisis revealed that the details of the default procedures were not well tested by the CCP as well as the clearing members and weaknesses were identified in the operational processes for replacing LBJ's position and making subsequent delivery of JGBs to non-defaulting participants. In managing the bankruptcy of LBJ, JGBCC successfully made cash payments to non-defaulting participants on time by obtaining cash from its committed lines of credit and by conducting repo transactions with market participants to cover the remaining liquidity gap. ${ }^{26}$ However, while these measures were clearly set out in its rules, it took more time for JGBCC to execute such repo transactions than expected.

\section{Shortening JGB settlement cycle for JGBs, which is currently $\mathbf{T}+3$, will help} reduce the replacement cost and liquidity pressures associated with managing a default of a market participant. A shorter settlement cycle would reduce the value of outstanding trades at the time of default of a market participant, which would reduce the value of contracts that need to be replaced, as well as the value of liquidity that needs to be obtained to cover the failure to pay by the defaulting party. As a first step, market participants have therefore agreed to shorten the settlement cycle by one day to $\mathrm{T}+2$ for outright transactions ( $\mathrm{T}+1$ for repos) as from April 23, 2012. Market participants are currently working to make necessary changes to their systems and operational processes for achieving $\mathrm{T}+2$. They intend to resume discussions in the second half of fiscal 2012 to reduce the settlement period further.

35. JGB fails practice have been reviewed and improved. Despite their introduction in 2001 along with the introduction of RTGS for JGB settlement, fails practice had not been fully adopted among participants — some institutional investors and financial institutions did

\footnotetext{
${ }^{25}$ In the stock market, in the absence of DVP settlement for stock lending transactions between financial institutions and institutional investors, some market participants engaged in stock lending transactions made delivery of shares to LBJ but could not take receipt of the corresponding funds, incurring losses.

${ }^{26}$ JGBCC obtains liquidity from: (i) cash portion of the initial margins; (ii) voluntary funding from participants or other parties with $\mathrm{T}+0$ repos, using JGBs received from non-defaulting participants and JGBs pledged as initial margins; and (iii) drawdown of committed lines of credit. Participants who are original counterparties of the defaulting participant are obliged to conduct $\mathrm{T}+0$ repo transactions with the JGBCC when liquidity gap remains.
} 
not accept fails from their counterparties. This was due to their lack of understanding of fails practice $^{27}$ (e.g., viewing settlement fail as an event of default) or lack of operational capability to process failed transactions. Although unavoidable fails are to be accepted, frequent occurrence of fails is undesirable. In light of the LBJ default's experience, market participants have agreed to introduce fails charges. The revised market practice, which became effective in November 2010, aimed to increase acceptance of fails practice across market participants while providing appropriate incentives to avoid fails. Market participants have developed business operations capable of handling fails and the payment and receipt of fails charges.

\section{Other market practices and technical developments could improve the} settlement of JBS transactions. These are: (i) securities substitution in repos; (ii) central queuing and loop resolution mechanisms in BOJ-NET JGB Services; and (iii) partial settlement. Substitution of securities between the start and end legs of repos would increase the JGB liquidity (the needed security being substituted by a less requested one). Even under normal market conditions, fails in government securities transactions occur due to a squeeze and loop transactions (a chain of transactions among several entities that begins and end with the same entity, thereby forming a loop). A way to resolve loops and therefore avoid related fails would be to introduce a central queuing and loop resolution mechanism in BOJ-NET JGB Services. Finally, a way to reduce the amount of fails would be to introduce a partial settlement facility (settling only a certain portion of the delivery amount and allowing the remainder to a fail). These measures are widely used around the world, and have proved their usefulness, but since they are costly to develop, both for the FMI and its participants, a collective analysis of their pros and cons should be conducted before taking any decision in this regard.

\section{The authorities and market participants have agreed on the objective to expand}

the use of JGBCC. Despite the weaknesses identified above, overall, JGBCC managed the LBJ default in accordance with its predefined risk management measures and contributed to maintain the overall stability of the JGB market. JGBCC currently clears approximately between 40 and 50 percent of the JGB market (outright and repo transactions). To expand the risk reduction and efficiency benefits of CCP across the JGB market, it has been suggested that a wider range of market participants make use of JGBCC. Trust banks have been identified as one segment of the market with low participation in JGBCC despite their large market presence. In December 2010, JGBCC agreed with the Trust Companies Association of Japan that it would make necessary changes to its systems and processes to address the needs of trust banks. In turn, trust banks agreed that they would aim to participate in JGBCC in 2014 for transactions associated with asset administration services.

\footnotetext{
${ }^{27}$ Fails Practice refers to market practices that define the general processing procedures to be taken by parties in case of a Fail. It prevents parties from regarding an uncompleted delivery of government securities itself as default and canceling the contract.
} 
38. JGBCC has been strengthening its operational and risk management functions through a number of measures, but contingency funding arrangements are still to be improved. In particular JGBCC has enhanced its governance through a capital and business alliance with JSCC. In September 2010, JGBCC issued new shares through a third party allotment, all of which was acquired by JSCC. As a result of this alliance, JGBCC is now owned 35.6 percent by JSCC and the rest by its participants (previously, it was 100 percent owned by participants). JSCC also assigned full-time executive and management-level personnel to JGBCC and JGBCC created a section dedicated to risk management. In May 2011, JGBCC put in place detailed internal procedures and automated processes for various aspects of default management including liquidation of defaulting participant's positions. The CCP also established clear rules on how to allocate bonds subject to settlement fails in line with the revision of the fails practice in November 2010. In addition, its core IT system has been renewed and additional IT functions, critical for conducting appropriate stress testing are being improved. Finally, JGBCC has been reviewing its contingency funding arrangements to ensure that it has reliable liquidity sources and operational processes; however, this action is still ongoing. Given the deteriorating financial conditions in some parts of the world and the associated rising risk of default, it is essential that the CCP and the authorities are ready to handle the default of the largest participant.

39. The authorities should put in place coordinated contingency plans to deal with a potential failure of a CCP, in line with the outcome of the ongoing discussions on this issue at the international level. CCPs are particularly vulnerable to wrong-way risk. ${ }^{28}$ That is, a CCP is most likely to be under stress at the same time as its participants and its liquidity providers. Further, the markets into which it must liquidate collateral are also most likely to be under stress at such times. Defining contingency policy and approach in advance for each CCP will allow the authorities to intervene with greater speed and communicate with the market even more quickly and effectively in the event of a crisis, and ultimately avoid a spillover effect. In particular, the authorities should identify in advance what resolution arrangements will apply to CCPs and in what manner. These would either allow the critical services of the CCP to be sustained or for the CCP's winding down in an orderly manner. Development of contingency plans to address CCP failures is not a requirement under existing standards, and international discussions on this issue are still on-going. This crucial issue is not specific to Japan and the Japanese authorities intend to address it when international discussions are finalized.

\section{Systemically important FMIs, including BOJ-NET JGB Services and JGBCC,} continued stable operation in the face of the March 2011 earthquake. The financial sector in Japan was seriously impacted by the disaster, in terms of both physical damage and indirect effects. Nevertheless, even in the aftermath of the earthquake, systemically important

\footnotetext{
${ }^{28}$ Wrong-way risk is defined by the International Swaps and Derivatives Association (ISDA) as the risk that occurs when "exposure to a counterparty is adversely correlated with the credit quality of that counterparty".
} 
FMIs continued to operate in a stable manner and managed to maintain their normal functioning. Despite the JMA seismic intensity of "5 lower" in the area of BOJ-NET main IT center, the systems were not damaged and funds and securities transfers over BOJ-NET were completed at the normal scheduled times. Most of the major payment and settlement systems operated by the private sector also completed settlements more or less at normal hours. BOJ-NET extended its cut-off times by one hour in the following week to allow later submission of payments by financial institutions that were facing increased workload due to the contingency conditions arising from planned blackouts and a system failure at a major financial institution.

41. The resilience to the Great East Japan Earthquake reflected the constant efforts made by FMIs and financial institutions to put in place robust business continuity arrangements prior to the disaster. Since the September 11, 2001, terrorist attacks in the United States, authorities, FMIs and market participants have largely improved their business continuity arrangements and have been testing them regularly. They have strengthened the earthquake resistance of the relevant facilities and developed procedures and systems that enable them to respond flexibly to emergency situations. The information sharing via dedicated websites, which has been implemented as part of market-wide business continuity arrangements, functioned smoothly following the earthquake, which was essential because of the disruption of telephone services even in the Tokyo metropolitan area, where the facilities of the major market infrastructures and financial institutions are concentrated.

\section{BOJ has identified issues for consideration by FMIs and market participants to} further enhance their business continuity arrangements, including organization of street-wide testing exercises on a regular basis. ${ }^{29}$ In particular, the disaster highlighted the importance of (i) increasing in-house power generating capabilities against potential longterm constraints on electricity supply; (ii) enhancing arrangements for securing necessary staff in the event of prolonged disruption of public transportation services; and (iii) securing system processing capacity to withstand a surge in trading activity. In addition, the central bank has stressed the need to pursue and enhanced the "street-wide exercises," with participation of the overall financial industry, which were launched in 2010, eventually with the cooperation of non-financial firms such as the providers of social infrastructure. In addition, as the operator of BOJ-NET, the Bank committed to further enhance its business continuity arrangements. Finally, through its day-to-day monitoring and oversight activities, as well as its onsite examinations, the Bank intends to encourage private-sector payment and settlement systems and financial institutions to strengthen their arrangements, and actively supports their initiatives to this end.

\footnotetext{
${ }^{29}$ See in particular BOJ's report on the Responses to the Great East Japan Earthquake by Payment and settlement Systems and Financial Institutions in Japan publicly disclosed in October 2011.
} 


\section{E. Spillover Risk Stemming from FMI Interdependencies}

\section{Tighter interdependencies have increased the potential for disruptions to spread} quickly and widely across multiple FMIs worldwide. Over the last decade, FMIs have become more interconnected, which has contributed to increase the efficiency of global FMIs by reducing settlement costs and in some instance settlement risks. Tighter direct relationships between FMIs, stronger indirect relationships arising from the activities of large financial institutions in multiple FMIs, and broader commonalities, such as the use of common third-party service providers, all has contributed to this trend. A good illustration of direct relationships between FMIs is the creation of the CLS system, the main FX transactions settlement system worldwide, which settles on a payment versus payment basis more than fifty percent of global currency trades daily in 17 major currencies, including the yen. CLS is directly linked to the national RTGS where pay-ins and pay-outs in each of the currencies occurs several times per day. An example of the use of a common provider is the development of SWIFT as a global network for financial messages: this network has been increasingly used over the years for bilateral financial transactions as well as FMIs' transactions. As a result, the smooth functioning of an individual system often depends on the smooth functioning of other related systems and technical infrastructure. Mitigating this risk requires that FMI operators, financial institutions, and service providers upgrade their risk management practices. In parallel, central banks and other authorities are expected to adjust their policies as needed in light of the challenges posed by interdependencies. ${ }^{30}$

\section{The spillover risk stemming from interdependencies with overseas FMIs has increased in the past decade but remains relatively limited in Japan. Main} interdependencies come from the use of CLS for yen FX transactions, the offshore central clearing of yen denominated OTC derivatives transactions, the participation of foreign financial institutions in Japanese FMIs, the offshore settlement of JGBs in the two largest International Central Securities Depositories (ICSDs), and the use of SWIFT as a financial messages network provider. However, the net settlement of CLS in BOJ-NET FTS amounts to less than one percent of the value of BOJ-NET FTS total settlement even though yen is the third largest currency settled in CLS, following US\$ and euro. For the offshore central clearing of yen denominated OTC derivatives transactions, according to SwapClear website, as of December 14, 2011, the outstanding notional of yen denominated IRS at the Londonbased CCP amounted to US\$38.4 trillion, which makes the yen the third currency cleared in SwapClear far behind the euro (US\$113.4 trillion) and US\$ (102.9 trillion). ICSDs participate in BOJ's JGB Book-Entry System as Foreign Indirect Participants, and the part of JGB settlement in the ICSDs seems limited. Finally, none of the Japanese FMIs currently

\footnotetext{
${ }^{30}$ For further detail on FMIs' interdependencies, please refer to the CPSS June 2008 report which identifies the various interdependencies that exist among the systems of CPSS countries, analyses the risk implications of these interdependencies, and assesses any associated risk management challenges (CPSS Publications No. 84, The interdependencies of payment and settlement systems).
} 
rely on the SWIFT network, which, in Japan, is rather used for bilateral transactions between financial institutions.

45. According to the policy statement disclosed on BOJ website, ${ }^{31}$ the scope of BOJ's oversight includes offshore yen payment systems. The central bank's oversight primarily focuses on FMIs located in Japan, but the scope of the BOJ's oversight also covers offshore yen payment systems which could have a significant impact on the safety and efficiency of payment arrangements in Japan. Specifically, the Bank places particular focus on systems that potentially have a significant impact on domestic payment arrangements should the system fail to perform as expected (the central bank considers, as a benchmark, whether the system has processed yen payment transactions exceeding $¥ 500$ billion on an average day during the past twelve months). The policy statement mentions that BOJ will seek to establish an international cooperative oversight arrangement for offshore systems with significant impact and that BOJ participates in cooperative oversight of CLS and SWIFT. Although SSSs and CCPs are currently not included in BOJ's offshore oversight policy statement, BOJ is participating in the international discussions among relevant authorities on the basic framework for cooperative oversight/supervision, as well as in the discussions on arrangements for individual FMIs (the former is being discussed in CPSS-IOSCO and the latter in the OTC Derivatives Regulator Forum). BOJ intends to review the scope of its offshore FMIs oversight in light of the outcome of these international discussions.

\section{It is important that the authorities continue monitoring the spillover risk} stemming from interdependencies with overseas FMIs. Determining whether an offshore FMI has the potential to have a significant impact depends on a combination of factors including the value and volume of yen transactions processed by the FMI and the degree of interdependency between the offshore and domestic FMIs. The FSA has signed the IOSCO Multilateral Memorandum of Understanding on consultation, corporation and information exchange among securities supervisory authorities, which enables, in particular, the FSA to exchange information on FMIs with securities supervisory authorities all over the world. Nevertheless, there is currently no concrete example of such information exchanges. Neither the FSA, nor BOJ currently gets sufficient information on offshore yen central clearing, but both authorities are participating in the discussions that are taking place in the OTC Derivatives Regulator Forum to develop information sharing agreements on individual FMIs, including LCH Clearnet Limited. In addition authorities explained that they monitored JGB offshore settlement and foreign FMIs participants. At a time when some other parts of the world are facing financial difficulties, it is strongly recommended to continue and even enhance such a monitoring to measure if the risk factors are changing and be prepared for a default of one of the relevant overseas FMIs or foreign financial institutions.

\footnotetext{
${ }^{31}$ See BOJ, Policy on Oversight of Offshore Yen Payment Systems, May 2010.
} 


\section{F. OTC Derivatives Central Clearing}

\section{Japan has undertaken the necessary steps to meet the G20 commitment to} centrally clear all standardized OTC derivatives. In 2009, G20 Leaders agreed in Pittsburgh that by end-2012 all standardized OTC derivative contracts should be cleared through CCPs. The objective is to better manage counterparty risk in the OTC derivatives market and thus improve the safety and resilience of the global financial system. The OTC derivatives market in Japan is still smaller in scale than those in the United States or Europe: according to BIS data, ${ }^{32}$ the notional amount of yen denominated single-currency interest rate derivatives was estimated at around US\$65 trillion at end-June 2011 (of which US\$58 trillion were interest rate swaps), out of a total of around US\$554 trillion for all reported currencies. Transactions between domestic participants are currently cleared on a bilateral basis, and transactions with overseas counterparties are mostly cleared on a bilateral basis and in SwapClear (LCH Clearnet Limited). ${ }^{33}$

\section{In December 2011, Japan was the only jurisdiction, with the United States, that} had adopted legislation mandating central clearing of standardized OTC derivatives by the end of 2012. The 2010 amended FIEA includes provisions to improve the stability and transparency of clearing and settlement of OTC derivatives transactions by requiring clearing organizations to be used and stipulating different possible clearing organizations depending on the characteristics of the transactions. The types of OTC derivatives transactions which will have to be centrally cleared are those that, "in light of the condition of the transactions, are regarded as having a material impact on the capital market of Japan in case of default of the transactions." Initially the requirements will apply only to yen interest rate swaps and CDS (iTraxx Japan indices). The law enables foreign CCPs to provide clearing services for domestic financial institutions in Japan either directly from abroad by obtaining a special license or indirectly by establishing a link with domestic financial instrument clearing institutions authorized as such. ${ }^{34}$ Legislative changes must be followed up with more technical implementing regulation for the requirements to be fully effective. In particular, the type of OTC derivative transactions which must be cleared by a Japanese CCP, a linked CCP, or a foreign CCP will be specified in Cabinet Ordinances.

\section{Central clearing services for yen denominated OTC derivatives will be offered} domestically, in parallel with offshore clearing. The JSCC launched clearing services for iTraxx Japan indices in July 2011 and plans to offer IRS clearing services by the end of 2012,

\footnotetext{
${ }^{32}$ The BIS semi-annual OTC derivatives markets statistics offer internationally consistent information on the size and structure of derivatives markets in the G10 countries and Switzerland, based on the reporting of the relevant central banks.

${ }^{33}$ According to SwapClear website, as of December 14, 2011, the outstanding notional of yen-denominated IRS at the London-based CCP amounted to US\$38.4 trillion, out of a total of US\$293 trillion for all currencies.

${ }^{34}$ Until now, no license has been provided and no link has been authorized.
} 
which would allow Japan to implement the G20 requirement on time. Central clearing for yen denominated IRS transactions is likely to be achieved in parallel in LCH Clearnet Limited and in JSCC. The establishment of a domestic CCP will help reduce the concentration of risk in the global CCP, allow direct access to clearing activities by smaller domestic participants, and enable authorities to exercise oversight of yen denominated derivatives domestic trading and clearing activities. However, the coexistence of several CCPs clearing the same type of transactions is likely to decrease the netting effect and increase the amount of posted collateral. Linking the domestic and global CCPs could be a solution, but the regulatory environment is not ready yet. In particular, the European Market Infrastructure Regulation does not extend the provisions on interoperability to instruments other than cash securities in view of the complexity of derivatives markets and the early stage of development of CCP clearing for OTC derivatives. Given that a sizable part of yendenominated OTC derivatives transactions is likely to be cleared in Swap Clear, it is essential the Japanese authorities are associated to the supervision and oversight of LCH Clearnet Limited through cooperative arrangements. 
ApPendix I. Overview of the Trading, Clearing and Settlement Organization

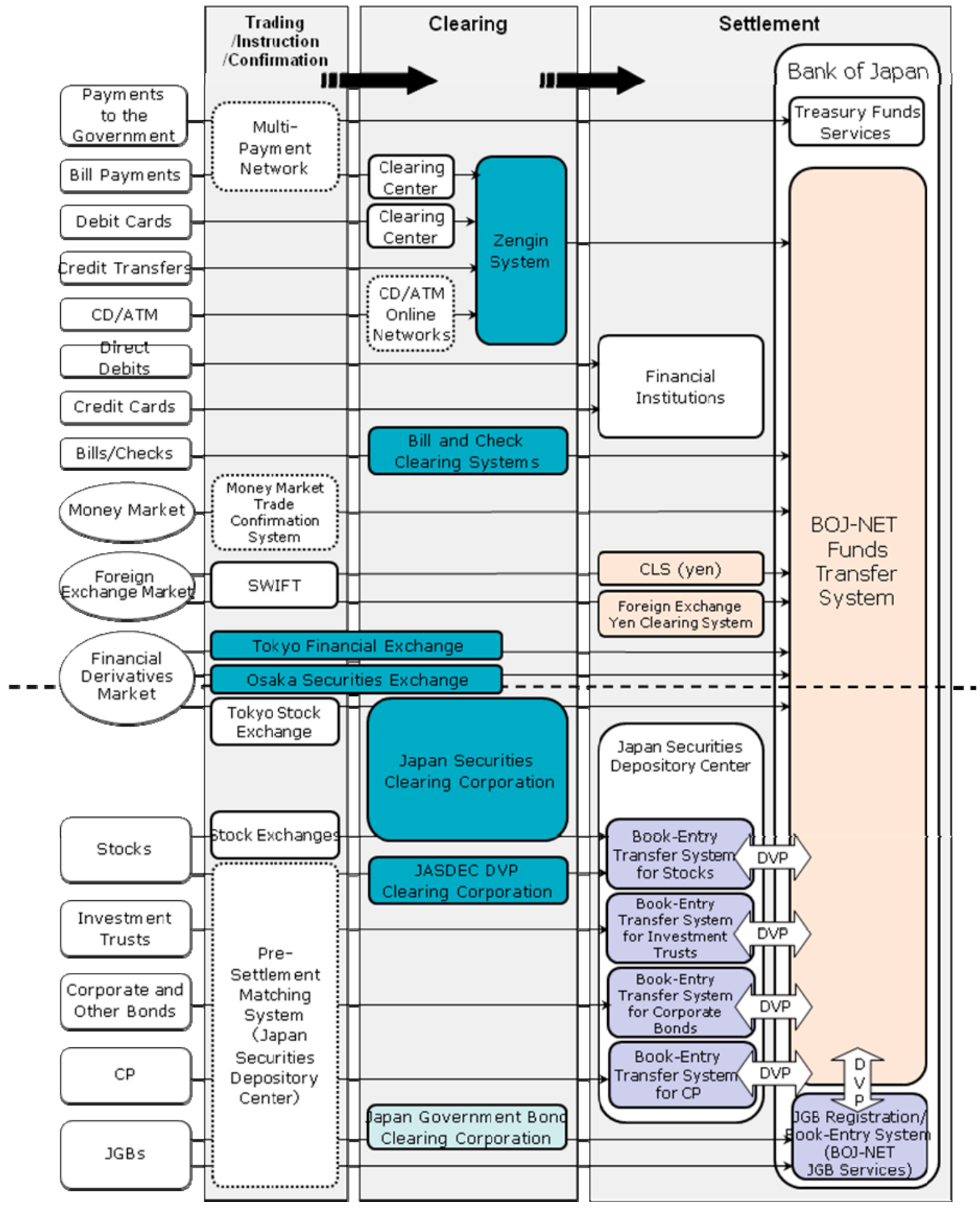

Source: BOJ 


\section{APPENDIX II. MAIN FEATURES OF BOJ-NET JGB SERVICES ${ }^{35}$}

50. The JGB Book-entry System is an arrangement for processing transfers of JGBs by crediting and debiting accounts on the books of participating institutions. Online processing services for the JGB Book-entry System are provided through the BOJ-NET JGB Services. JGB settlements are processed on a DVP basis by linking the BOJ-NET JGB Services to the BOJ-NET FTS.

\section{Institutional framework}

51. The JGB Book-entry System is operated by the Bank of Japan as the book-entry transfer institution under the Book-entry Act. The BOJ-NET JGB Services, a computer network system, is owned and operated by the Bank of Japan. The Policy Board of the Bank of Japan functions as the ultimate decision-making body for operation of the JGB Book-entry System and the BOJ-NET JGB Services. Transfers of JGBs under the JGB Book-entry System are governed by the Book-entry Act and other relevant laws, as well as by rules and procedures established by the Bank of Japan pursuant to these laws.

52. Pursuant to Article 47 of the Book-entry Act, the Bank of Japan is subject to regulations on book-entry transfer institutions. Unlike other book-entry transfer institutions (stock corporations), however, the Bank of Japan is exempted from regulations regarding the prohibition of other business, the dismissal or disqualification of executives, onsite inspections, and financial reporting and improvement orders, as a special exception permitted by Article 48 of the Act.

\section{Participation}

53. The JGB Book-entry System has three types of participants: direct participants, indirect participants and foreign indirect participants (FIP). Access criteria for the JGB Book-entry System are disclosed to the public and require applicants to be in sound financial condition and have appropriate operational ability. Financial condition is assessed based on capital adequacy ratios, and specific criteria are set according to the type of institution. As of June 2011, 298 direct participants, 1,015 indirect participants and 128 FIPs participated in the JGB Book-entry System.

\section{Types of transactions}

54. The types of securities processed in the JGB Book-entry System are limited to JGBs, and payments are made only in yen.

\footnotetext{
${ }^{35}$ Source: BIS Redbook 2012 (forthcoming).
} 


\section{Operation of the system}

55. The BOJ-NET JGB Services process final settlements of JGB transfers, both on a DVP and a free of payment (FOP) basis, continuously throughout the day on an RTGS basis. The BOJ-NET provides DVP services by linking the BOJ-NET FTS with the BOJ-NET JGB Services. The input hours for online instructions and the processing hours for the BOJ-NET JGB Services are 09:00-16:30.

56. BOJ provides a liquidity-saving facility for DVP settlement-i.e. simultaneous processing of DVP and collateralization (SPDC). By using this facility, a financial institution buying JGBs can post the JGBs receiving from the seller as collateral for an intraday overdraft from the Bank of Japan and simultaneously use the funds drawn to pay the seller. JGBs can be posted and returned any time during the operating hours of the BOJ-NET JGB Services.

57. The timing of final settlements of JGB transfers on an RTGS basis through the BOJ-NET is defined by contracts between the BOJ and BOJ-NET users as follows. A transfer of JGBs becomes final when the receiver's JGB account is credited on its transfer account book. The transfer of the corresponding funds becomes final when the current account of the receiver (i.e., a cash settlement agent) held at the BOJ is credited.

\section{Risk management}

58. The BOJ-NET JGB Services do not accept transfer instructions that would create debit positions in JGB accounts.

\section{Links}

The JGB Book-entry System and the BOJ-NET JGB Services maintain no direct linkages with overseas FMIs.

\section{Pricing}

59. The BOJ covers the costs of developing and maintaining the system infrastructure at its own expense because it operates these systems to contribute to the achievement of its objectives under the Bank of Japan Act-i.e., to ensure smooth settlement of funds among banks and other financial institutions. The BOJ charges users of the BOJNET JGB Services fees for "online instructions" made through the services under the "beneficiary pays" principle, and recovers the costs of external linkages (such as the costs of hardware and software necessary for external linkages and the cost of using of the online circuit). 


\section{APPENDiX III. MaIn Features OF THE JAPAN GovernMent Bond Clearing CORPORATION (JGBCC) ${ }^{36}$}

\section{Institutional framework}

60. The JGBCC was established in October 2003, as a central counterparty for Japanese government bonds and started clearing operations in May 2005. The backdrop to its establishment was the change in the settlement method of the BOJ-NET JGB Services from DNS to RTGS in 2001. JGBCC requires clearing participants to be shareholders of the JGBCC. Previously, the JGBCC was wholly owned by its participants; since September 2010, 35.6 percent has been owned by the JSCC and the rest by its participants.

\section{Participation}

61. The JGBCC had 35 clearing participants as of August 2011, which consisted of 25 securities firms, five banks, three money market brokers and two other financial institutions.

62. The JGBCC sets criteria for obtaining and maintaining the qualifications for participation. The JGBCC regularly monitors participants for their management practices, operational reliability, and financial standing. The JGBCC delegates the monitoring of participants' financial standing to the JSCC to reduce the burden on participants that participate in both CCPs. Financial requirements are set for each type of institution. For example, the financial requirements for securities companies are (i) capital of over $¥ 300$ million; (ii) net assets of over $¥ 5$ billion; and (iii) a capital to risk ratio of over 200 percent. The JGBCC has the right to suspend assumption of participants' obligations and revoke their qualifications.

\section{Types of transactions}

63. The JGBCC clears outright and repo transactions in JGBs that are executed between participants in the OTC market. Term of repo transactions subject to clearing by the JGBCC is less than one year. Types of JGBs eligible for clearing are FBs, TBs, interestbearing bonds, discount bonds, floating rate bonds and STRIPs.

\footnotetext{
${ }^{36}$ Source: BIS Redbook 2012 (forthcoming).
} 


\section{Operation of the system}

\section{The clearing process is as follows:}

I. A seller and a buyer of a JGB transaction transmit trade data to the matching system, PSMS, operated by JASDEC.

II. PSMS matches and confirms the trade information and sends the confirmation results to the JGBCC.

III. At 18:30 on the trade date, the JGBCC assumes participants' obligations, and becomes the seller to every buyer and the buyer to every seller.

IV. Transactions between the JGBCC and each participant are netted into one position by type of securities and by settlement date. As the standard settlement cycle for JGBs is $\mathrm{T}+3$, the JGBCC typically takes on counterparty risk for three days for an outright trade. The JGBCC notifies participants of the net positions and the settlement details for the following day.

V. On the settlement date, both the seller and the buyer settle their resulting net positions on a DVP basis through the BOJ-NET FTS and the BOJ-NET JGB Services. There are two steps involved in DVP settlement, that is, DVP1 and DVP2. In DVP1, the seller delivers JGBs to the JGBCC, which pledges them to the Bank of Japan as collateral for an intraday overdraft using the simultaneous processing of DVP and collateralization (SPDC) function. At the same time, the JGBCC pays for the JGBs received from the seller with the funds provided by the overdraft. In DVP2, the buyer makes its payment for the JGBs to the JGBCC, which in turn repays the intraday overdraft to the Bank of Japan using the payment so received. At the same time, the JGBCC receives the pledged JGBs from the BOJ and delivers the JGBs to the buyer. In the collateralization process, the amount of the haircut is made up for by collateral pledged to the Bank of Japan in advance.

65. By using RTGS systems for settlement of both funds and securities, the JGBCC adopts gross-gross DVP (DVP model I), with net positions of both funds and securities calculated for each type of securities. The JGBCC sets the deadlines for DVP1 and DVP2 at 13:30 and 14:00, respectively. In practice, however, settlement of almost all net positions is completed in the morning in line with the market guidelines for settlement of JGB transactions.

66. Funds only settlement (FOS) takes place over the BOJ-NET FTS. Variation margin calls comprise a major part of FOS. Market prices are used as clearing prices for individual securities, and differences between trade prices and clearing prices are adjusted in FOS.

\section{Risk management}

67. The JGBCC has various procedures to mitigate credit and liquidity risk. In the event that the defaulting participant's "clearing fund deposits" as initial margin were 
insufficient to cover the loss, the following financial resources would be applied: (i) funds from participants who are original counterparties of the defaulting participant to share the remaining loss in proportion to their net settlement amount with the defaulting participant; (ii) a quarter of the retained earnings of the JGBCC; and (iii) additional funds from all nondefaulting participants.

68. The clearing fund as initial margin plays a key role in covering the loss that may arise from the default of a participant. The margin calculation method is therefore set conservatively with some backups against volatility in both prices and positions. The amount of initial margin is subject to downward rigidity such that once the amount of the initial margin goes up due to a rise in price volatility and/or an increased position; the highest watermark continues to hold for a substantial period of time. In addition, the required amount based on daily figures is designed to cover the average of recent peak values in these figures. The first-loss sharing scheme, in which participants who are original counterparties of the defaulting participant are required to deposit additional funds in proportion to their net settlement amount with the defaulting participant, is expected to make participants reluctant to trade with a counterparty with deteriorating financial condition. Clearing funds may be provided in JPY cash or JGBs.

69. Participants with a shortfall in FOS and clearing funds are required to deliver the necessary amount of funds or collateral by 10:00 and 11:00 on the following business day, respectively. Clearing funds are also designed to cover the risk of failure by a participant to make the FOS payment, which includes variation margin. The JGBCC can also raise margin requirements when the financial condition of a participant deteriorates.

70. The JGBCC has arrangements for addressing liquidity risk in the event of a participant's default. The JGBCC obtains liquidity from: (i) cash portion of the clearing funds; (ii) funding from participants or other parties with $\mathrm{T}+0$ repos, using JGBs received from non-defaulting participants and JGBs pledged as clearing funds; and (iii) drawdown of committed lines of credit. Participants who are original counterparties of the defaulting participant are obliged to conduct $\mathrm{T}+0$ repo transactions with the JGBCC when it has a liquidity shortfall.

\section{Links to other systems}

71. Settlement of the net positions in the JGBCC takes place on a DVP basis over the BOJ-NET FTS and the BOJ-NETJGB Services, using the current account and JGB account that the JGBCC holds with the Bank of Japan. The SPDC function provided through these systems plays a key role in realizing DVP under RTGS.

72. The JGBCC also has a link to the PSMS operated by JASDEC to receive confirmation results for trades executed between clearing participants. 
73. The JGBCC does not have cross-margin arrangements across CCPs and does not maintain cross-border arrangements or clearing links with overseas securities settlement systems.

\section{Pricing}

74. The JGBCC charges participants with clearing fees based on the value of transactions cleared for each participant, which subject to a maximum amount.

Settlement fees are set at a fixed rate per DVP transaction. These fee rates vary depending on transaction type, including whether the transaction is an outright or a repo transaction. The JGBCC also charges fees for counterparty risk based on the net outstanding positions, which is charged mainly for term repo transactions. There are also fixed fees for maintaining an account and terminals. 


\section{APPENDIX IV. OVERVIEW OF THE OVERSIGHT AND SUPERVISION FRAMEWORK FOR MAJOR FMIS}

\begin{tabular}{|c|c|c|c|c|c|c|}
\hline FMI Type & $\begin{array}{l}\text { Owner } \\
\text { ship }\end{array}$ & FMI & $\begin{array}{l}\text { Authorization, Designation, } \\
\text { or Licensing }\end{array}$ & Oversight by BOJ & Supervision by Governmental agencies & $\begin{array}{c}\text { Onsite } \\
\text { Inspection } \\
37,38\end{array}$ \\
\hline \multirow{4}{*}{$\begin{array}{l}\text { Payment } \\
\text { systems }\end{array}$} & Public & $\begin{array}{l}\text { BOJ-NET } \\
\text { FTS }\end{array}$ & $\begin{array}{l}\text { Domestic fund transfers } \\
\text { directly authorized in BOJ Act. } \\
\text { Authorization needed from } \\
\text { Prime Minister and Minister of } \\
\text { MOF to conduct related } \\
\text { business to contribute to the } \\
\text { smooth settlement of funds } \\
\text { (i.e., communication network) }\end{array}$ & $\begin{array}{l}\text { Payment and } \\
\text { Settlement System } \\
\text { department at BOJ } \\
\text { assesses the system } \\
\text { against international } \\
\text { standards }\end{array}$ & $\begin{array}{l}\text { Coordination Division in the Supervisory Bureau } \\
\text { of the FSA + Financial System Stabilization } \\
\text { Division of the MOF for the initial authorization } \\
\text { of the communication network, the correction of } \\
\text { the Violation of Acts and the collection of } \\
\text { Reports }\end{array}$ & \\
\hline & \multirow{3}{*}{ Private } & $\begin{array}{l}\text { Payment } \\
\text { clearing } \\
\text { institution } \\
\text { (Zengin- } \\
\text { Net) }\end{array}$ & Licensing by Prime Minister & $\begin{array}{l}\text { BOJ Payment and } \\
\text { Settlement System } \\
\text { department }\end{array}$ & Bank I Division at Supervisory Bureau of FSA & $\begin{array}{l}\text { Inspection } \\
\text { Bureau at } \\
\text { FSA }\end{array}$ \\
\hline & & FXYCS & $\begin{array}{l}\text { BOJ got authorization from } \\
\text { Prime Minister and Minister of } \\
\text { MOF to have an agreement } \\
\text { with Japanese Bankers } \\
\text { Association to operate FXYCS } \\
\text { (Art. } 39 \text { of BOJ Act) }\end{array}$ & $\begin{array}{l}\text { BOJ Payment and } \\
\text { Settlement System } \\
\text { department }\end{array}$ & None & \\
\hline & & $\begin{array}{l}\text { Bill and } \\
\text { Check } \\
\text { Clearing } \\
\text { House }\end{array}$ & $\begin{array}{l}\text { Designation by Minister of } \\
\text { MOJ }\end{array}$ & $\begin{array}{l}\text { BOJ Payment and } \\
\text { Settlement System } \\
\text { department }\end{array}$ & $\begin{array}{l}\text { The Commercial Division in the Civil Affairs } \\
\text { Bureau }\end{array}$ & \\
\hline
\end{tabular}

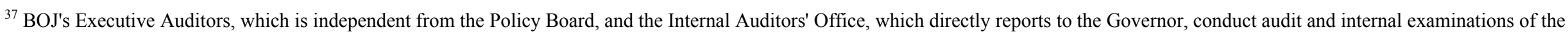

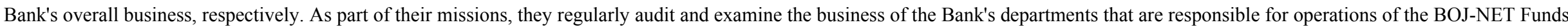
Transfer System and JGB Services.
}

${ }^{38}$ BOJ's Financial System and Bank Examination Dept. also conducts onsite examination of FMIs with which the BOJ has an examination contract. 


\begin{tabular}{|c|c|c|c|c|c|c|}
\hline \multirow{2}{*}{$\begin{array}{l}\text { Securities } \\
\text { settlement } \\
\text { systems }\end{array}$} & Public & $\begin{array}{l}\text { BOJ-NET } \\
\text { JGB } \\
\text { Services }\end{array}$ & $\begin{array}{l}\text { Designation by Prime } \\
\text { Minister, with delegation to } \\
\text { FSA, Minister of MOJ and } \\
\text { MOF }\end{array}$ & $\begin{array}{l}\text { Payment and } \\
\text { Settlement System } \\
\text { department at BOJ } \\
\text { assesses the system } \\
\text { against international } \\
\text { standards }\end{array}$ & $\begin{array}{l}\text { Financial Market division of the Coordination } \\
\text { and Planning Bureau at FSA + Commercial } \\
\text { Division of Civil Affairs Bureau at the MOJ+ } \\
\text { Debt Management Policy Division of the } \\
\text { Financial bureau at the MOF }\end{array}$ & \\
\hline & Private & JASDEC & $\begin{array}{l}\text { Designation by Prime } \\
\text { Minister, with delegation to } \\
\text { FSA, Minister of MOJ }\end{array}$ & $\begin{array}{l}\text { Payment and } \\
\text { Settlement System } \\
\text { department at BOJ }\end{array}$ & $\begin{array}{l}\text { Financial Market division of the Coordination } \\
\text { and Planning Bureau at FSA + Commercial } \\
\text { Division of Civil Affairs Bureau at MOJ }\end{array}$ & $\begin{array}{l}\text { SESC+ } \\
\text { Commercial } \\
\text { Division of } \\
\text { Civil Affairs } \\
\text { Bureau at } \\
\text { MOJ }\end{array}$ \\
\hline CCPs & Private & $\begin{array}{l}\text { JGBCC } \\
\text { JSCC } \\
\text { JDCC } \\
\text { OSE } \\
\text { TFX }\end{array}$ & $\begin{array}{l}\text { Licensing by Prime Minister, } \\
\text { with delegation to FSA }\end{array}$ & $\begin{array}{l}\text { Payment and } \\
\text { Settlement System } \\
\text { department at BOJ }\end{array}$ & $\begin{array}{l}\text { Financial Market division of the Coordination } \\
\text { and planning Bureau at FSA for securities and } \\
\text { financial derivatives }\end{array}$ & SESC \\
\hline
\end{tabular}

